\title{
New Lower Kimmeridgian ataxioceratin ammonite from the eastern Iberian Chain, Spain: Systematic, biogeographic and biostratigraphic relevance
}

\author{
Luis Moliner and Federico Olóriz \\ Acta Palaeontologica Polonica 55 (1), 2010: 99-110 doi: http://dx.doi.org/10.4202/app.2008.0064
}

New ammonites collected bed-by-bed from the upper part of Ataxioceras hypselocyclum Chronozone deposits in the eastern Iberian Chain are described as Geyericeras gen. nov. The new genus includes micro- and macroconchiate Ataxioceratinae of small size, with moderate to loose coiling and subpolyplocoid ribs, a character crucial for its identification. Key points for the comparative identification of Geyericeras gen. nov. are: (i) microconchiate Geyericeras show morphological convergence with evolute specimens of the stratigraphically older genus Schneidia [m]; (ii) contemporary Ataxioceratinae genera such as Ardescia [m, M] and Lithacosphinctes [m, M] did not develop subpolyplocoid ribbing; (iii) smoothing of sculpture combined with short primary ribs are not realized in Geyericeras gen. nov. $[\mathrm{M}]$ and can be therefore used to separate the new genus from Ataxioceras $[\mathrm{M}]$; and (iv) smaller shells, and weaker and less dense ribbing with no parabolic structures differentiate Geyericeras gen. nov. [m, M] from Parataxioceras $[\mathrm{m}, \mathrm{M}]$, as well as the type of subpolyplocoid ribs seen among microconchiate specimens of these two genera. The new species Geyericeras aragoniense sp. nov. is the index and guide fossil for identification of a biohorizon occurring below the first occurrence of the genus Crussoliceras in the eastern Iberian Chain.

Key words: Ammonoidea, Geyericeras, Ataxioceratinae, Lower Kimmeridgian, Jurassic, Iberian Chain, Spain.

Luis Moliner [lmoliner@ensaya.es],ENSAYA Laboratory, Aneto no 8, 50410 Cuarte de Huerva, Zaragoza, Spain;; Federico Olóriz [foloriz@ugr.es], Department of Stratigraphy and Paleontology, Faculty of Sciences, University of Granada, Av. Fuentenueva s/n, 18002 Granada, Spain. 
Attribution License (for details please see creativecommons.org), which permits unrestricted use, distribution, and reproduction in any medium, provided the original author and source are credited.

PoFif Full text $(471.0 \mathrm{kB})$ 